\title{
Single-dose treatment of uncomplicated gonorrhoea in males with minocycline
}

\author{
M. SHAHIDULLAH \\ Special Treatment Centre, Nottingham General Hospital
}

Gonorrhoea is a major public health problem and the increasing prevalence of strains with reduced sensitivity to penicillin makes the situation worse. Any alternative standard treatment should fulfil the usual criteria in terms of cost, efficacy, and lack of sideeffects. It should preferably be injectable, but any treatment which can be given orally in one supervised dose merits consideration. Pariser and Marino (1970), Thatcher, Pazin, and Domescik (1970), and Duncan, Glicksman, Knox, and Holder (1971) in the U.S.A. gave conflicting reports of the success of minocycline in the treatment of gonorrhoea. A trial of this drug was, therefore, thought desirable.

\section{Material and methods}

The trial was conducted at the Special Treatment Centre at Nottingham General Hospital.

103 male patients with culture positive uncomplicated gonorrhoea were studied. They had had no antibiotic or other therapy before attendance. 55 were British, 44 West Indian, three Irish, and one Australian.

The average age was 26 years (range 15 to 44 ) (Table I).

TABLE I Age distribution

\begin{tabular}{ll}
\hline Age $(y r s)$ & No. of patients \\
\hline $15-19$ & 24 \\
$20-29$ & 43 \\
$30-39$ & 28 \\
$40-45$ & 8 \\
\hline
\end{tabular}

\section{CLINICAL PRESENTATION}

53 patients complained of urethral discharge and dysuria, 43 of urethral discharge only, and five of dysuria only; one complained of irritation of the prepuce, and one was asymptomatic.

Symptoms had been present for 1 to 3 days in 47 patients, 4 to 7 days in 42,1 to 2 weeks in eleven, and 2 to 4 weeks in three.

\section{LABORATORY INVESTIGATIONS}

Initial diagnosis was made by microscopical demonstration of intracellular Gram-negative diplococci in stained

Received for publication June 25, 1974 smears of urethral discharge, but all cases included were confirmed by positive culture on Philips medium (Oxoid DSA base with 7 per cent. lysed horse blood).

Urine was examined by the two-glass method for haze and threads. Blood samples for routine serological tests for syphilis were taken from all patients.

\section{TREATMENT SCHEDULE}

Each patient received under supervision three $100 \mathrm{mg}$. tablets of minocycline (7-dimethylamine-6-deoxy-6demethyltetracycline hydrochloride). They were instructed to refrain from sexual intercourse and alcohol and to drink bland fluids liberally.

FOLLOW-UP

Patients were asked to attend after 3 to 4 days, and then $1,2,4,8$, and 12 weeks after treatment. At these visits they were examined for urethral discharge and the urine was examined for threads. Stained preparations were made if either were present. The demonstration of intracellular Gram-negative diplococci within 2 weeks after treatment was interpreted as a failure of treatment in the absence of admitted risk of infection. The finding of Gram-negative diplococci later than 2 weeks after treatment was regarded as a re-infection. The presence of pus cells in urethral material or of urinary threads up to 2 weeks after treatment was regarded as resolving gonococcal urethritis and no further treatment was given; persistence of pus for more than 2 weeks after treatment was diagnosed as nongonococcal urethritis and treatment was given.

Of the 103 patients treated, nine defaulted immediately after treatment, six after 3 days, and three after 1 week. The remaining 85 patients $(82.5$ per cent.) were followed for from 2 to 12 weeks.

\section{Results}

These are shown in Table II. Follow-up on individual patients ranged from 3 days to 3 months. The eighteen patients who failed to attend for a minimum period of 2 weeks after their initial treatment were regarded as defaulters and excluded from the trial.

Curtis and Wilkinson (1958), in a study of gonococcal penicillin sensitivities, regarded as cases of treatment failure those in which gonorrhoea reappeared within 1 week after treatment, regardless 
TABLE II Results

\begin{tabular}{|c|c|c|c|c|c|c|c|}
\hline $\begin{array}{l}\text { Total number } \\
\text { treated }\end{array}$ & $\begin{array}{l}\text { No. of patients } \\
\text { defaulted before } \\
2 \text { wks }\end{array}$ & $\begin{array}{l}\text { No. followed at least } \\
2 \text { wks after treatment }\end{array}$ & \multicolumn{2}{|l|}{ Failures } & $\begin{array}{l}\text { Non- } \\
\text { gonococcal } \\
\text { urethritis }\end{array}$ & Re-infections & $\begin{array}{l}\text { Percentage } \\
\text { cured }^{\star}\end{array}$ \\
\hline 103 & 18 & 85 & 3 & 2 & 10 & 7 & $94 \cdot 1$ \\
\hline
\end{tabular}

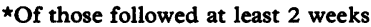

of any history of re-exposure. Applying this to the present study, there were three failures $(3.5$ per cent.), giving a cure rate of 96.5 per cent. of those followed-up. With our own criteria involving the first 2 weeks after treatment, the number of failures was five (5.9 per cent.) and the cure rate 94.1 per cent. Failures were confirmed by Gram-stained smear and culture and four were retreated successfully with intramuscular penicillin in routine dosage. The fifth patient harboured a gonococcus with reduced sensitivity to penicillin and was treated successfully with kanamycin. All patients regarded as cases of reinfection admitted re-exposure, and all were successfully treated with intramuscular penicillin. There were no re-infections within the first 2 weeks after treatment.

\section{Discussion}

It appears that a single dose of $\mathbf{3 0 0} \mathrm{mg}$. minocycline is an effective treatment for uncomplicated urethral gonorrhoea in males.

There are no uniformly applied criteria for assessing cure, re-infection, and relapse, so that comparison with other workers' results is not completely valid. However, the 94.1 per cent. cure rate in this study is comparable with the 95.5 per cent. success reported by Thatcher and others (1970), who used the same dosage and were able to follow 110 patients out of 137 treated.

Pariser and Marino (1970), using $250 \mathrm{mg}$. minocycline, reported rates of success varying from 68.6 to 92.5 per cent. depending on how the assessment was made. Using criteria similar to those in the present trial their success rate would be 87.9 per cent. The lower dosage used in their trial may be responsible for the lower cure rate. Duncan and others (1971) used the $300 \mathrm{mg}$. dosage, but followed only sixteen of 31 patients treated and reported a success rate of 75 per cent. Other trials using $200 \mathrm{mg}$. and $400 \mathrm{mg}$. were rendered inconclusive by high default rates.

Thatcher and others (1971) reported nausea and vomiting in one of 55 patients followed. No sideeffects were found in this series, even on direct questioning.

\section{Summary and conclusions}

Minocycline in a single $300 \mathrm{mg}$. oral dose was given to 103 men with uncomplicated gonorrhoea, of whom 85 were followed-up for at least 2 weeks. The cure rate in the 85 followed was $94 \cdot 1$ per cent. There were no side-effects.

Thus minocycline could be considered as an effective and safe alternative to penicillin in the single-dose treatment of uncomplicated gonorrhoea in the male, but at the moment it is too expensive for routine use.

I wish to thank Dr. J. B. Bittiner for permission to carry out this trial and Dr. R. Statham for his help in the presentation of this paper.

I am grateful also for the assistance of the nursing and secretarial staff and for the consistent support of the Nottingham Public Health Laboratory. I also thank the contact tracers for their diligent work. Most of the minocycline (Minocin) was supplied by Messrs. Lederle Laboratories, Ltd., with a supplement from the pharmacy at the General Hospital, Nottingham.

\section{References}

Curtis, F. R., and Wilkinson, A. E. (1958) Brit. f. vener. Dis., 34, 70

Duncan, W. C., Glicksman, J. M., Knox, J. M., and HOLDER, W. R. (1971) Ibid., 47, 364

Pariser, H., and Marino, A. F. (1970) Antimicrob. Agents and Chemother., 10, 211

Thatcher, R. W., Pazin, G., and Domescik, G. (1970) Publ. Hlth Rep. (Wash.), 85, 160

Traitement de la gonococcie masculine non compliquée par une dose unique de minocycline

\section{SOMMAIRE}

La minocycline fut donnée oralement en dose unique de $300 \mathrm{mg}$ à 103 hommes atteints de gonococcie non compliquée, dont 85 furent suivis pendant deux semaines au moins. Chez les 85 suivis, le taux de guérison fut de 94,1 pour cent. Il n'y eut pas d'effet secondaire.

Ainsi, la minocycline peut être considérée comme une alternative efficace et sûre de la pénicilline dans le traitement par dose unique de la gonococcie non compliquée chez l'homme, mais, actuellement, le traitement est trop coûteux pour une utilisation de routine. 